\title{
The Pharmabiotic Approach to Treat Hyperammonemia
}

\author{
Jing Liu ${ }^{1,+}$, Enkhchimeg Lkhagva ${ }^{1,+}$, Hea-Jong Chung ${ }^{1}$, Hyeon-Jin Kim ${ }^{2}$ and \\ Seong-Tshool Hong ${ }^{1, *}$ \\ 1 Department of Biomedical Sciences and Institute for Medical Science, Chonbuk National University Medical \\ School, Jeonju, Chonbuk 54907, Korea; 2011liujing88@gmail.com (J.L.); enkhchmg2580@gmail.com (E.L.); \\ hjchung@chonbuk.ac.kr (H.-J.C.) \\ 2 JINIS BDRD institute, JINIS Biopharmaceuticals Co., 913 Gwahak-Ro, Bongdong, Wanju, Chonbuk 55321, \\ Korea; hyeonjin_kim@yahoo.com \\ * Correspondence: seonghong@chonbuk.ac.kr; Tel.: +82-63-270-3105 \\ + These authors contributed equally to this work.
}

Received: 5 December 2017; Accepted: 26 January 2018; Published: 28 January 2018

\begin{abstract}
Ammonia is constantly produced as a metabolic waste from amino acid catabolism in mammals. Ammonia, the toxic waste metabolite, is resolved in the liver where the urea cycle converts free ammonia to urea. Liver malfunctions cause hyperammonemia that leads to central nervous system (CNS) dysfunctions, such as brain edema, convulsions, and coma. The current treatments for hyperammonemia, such as antibiotics or lactulose, are designed to decrease the intestinal production of ammonia and/or its absorption into the body and are not effective, besides being often accompanied by side effects. In recent years, increasing evidence has shown that modifications of the gut microbiota could be used to treat hyperammonemia. Considering the role of the gut microbiota and the physiological characteristics of the intestine, the removal of ammonia from the intestine by modulating the gut microbiota would be an ideal approach to treat hyperammonemia. In this review, we discuss the significance of hyperammonemia and its related diseases and the efficacy of the current management methods for hyperammonemia to understand the mechanism of ammonia transport in the human body. The possibility to use the gut microbiota as pharmabiotics to treat hyperammonemia and its related diseases is also explored.
\end{abstract}

Keywords: hyperammonemia; pharmabiotics; ammonia; gut microbiota

\section{Hyperammonemia and Its Related Diseases}

Ammonia in the human body is produced mostly as a byproduct of protein digestion and bacterial metabolism in the gut [1]. The kidney and muscle also generate a significant amount of ammonia. Within the kidney, ammonium is produced from glutamine in the proximal tubule, is concentrated in the medullary interstitium, and is then released into the blood circulation system or excreted into the urine, facilitating the secretion of protons [2]. When the glucose levels are decreased by starvation or intense exercise, the skeletal muscle can also generate ammonia through amino acid catabolism [3]. The majority of ammonia is either reutilized for the biosynthesis of nitrogenous compounds such as amino acids, or converted to urea by the urea cycle, and only a small amount of the remainder ammonia is released into the blood. Because free ammonia is very toxic, especially to neurons, ammonia is rapidly converted to nontoxic urea by the urea cycle in the liver and excreted in the urine eventually. Thereby, blood ammonia can be maintained at its safe concentration levels below $50 \mu \mathrm{M}$ in healthy adults [4]. In the case of inherited urea cycle disorders or liver diseases, blood ammonia levels increase and eventually cause subsequent diseases, such as neurologic disorders, hepatic encephalopathies, Reye syndrome, and some toxic encephalopathies [5]. 
The direct consequence of hyperammonemia is represented by neurological disorders which include alterations of mood and personality, cognitive impairment, ataxia, convulsions, and coma [6]. The severity of the neurological dysfunction depends upon the chronic or acute type of hyperammonemia, the degree of hyperammonaemia, and the age of the patient. Neuropathological studies revealed that Alzheimer type II astrocytosis was observed in the adult hyperammonaemic patient, whereas hyperammonemia in the infant with congenital urea cycle-related genes defects or Reye syndrome was always accompanied by cerebral atrophy, neuronal loss, and cerebral edema [6]. Reye syndrome, a rapidly progressive encephalopathy, is a rare but serious pediatric condition [7]. It was much more common among children and teenagers when aspirin was commonly prescribed to them, but virtually disappeared after warnings about prescribing aspirin to children and teenagers [7]. In the USA, it is advised that anyone under 19 years of age should not be given any medication containing aspirin unless on the advice of a doctor [8]. Likewise, in the UK, aspirin should not be given to anyone under the age of 16 years unless on the advice of doctors [9].

In hyperammonemia, blood ammonia is transported to the brain through the blood-brain barrier. The flux that moves into the brain is most likely both by diffusion of gaseous $\mathrm{NH}_{3}$ and by mediated transport of $\mathrm{NH}_{4}{ }^{+}$by channels and transporters through plasma membrane crossing, which will have a direct effect on the $\mathrm{pH}$. Furthermore, $\mathrm{NH}_{4}{ }^{+}$competes with $\mathrm{K}^{+}$on $\mathrm{K}^{+}$transporters, affecting the membrane potentials. A cascade of secondary effects and encephalopathy will result from these direct effects of elevated ammonia concentrations on the brain [10].

Hepatic encephalopathy (HE) is a hyperammonemia-related complication secondary to an acquired liver function impairment. It can be a serious complication resulting from acute liver failure or chronic liver diseases, predominantly liver cirrhosis. Patients with acute liver failure (ALF) develop HE and subsequently symptomatic cerebral edema (CE) with progression into cerebral herniation. Patients with chronic liver diseases also develop HE but rarely symptomatic CE, even though marginally increased cerebral water content can be demonstrated in MRI [11].

When in the hyperammonemia condition, the renal ammoniagenesis is decreased and excretion into urine is increased [12]. In addition, the muscles and brain convert excess ammonia to glutamine. Under normal physiological conditions, glutamine is deaminated to glutamate in neurons, which is stored in vesicles and then released into the synaptic clefts where it initiates an excitatory signal by binding to the $N$-methyl-D-aspartate (NMDA) receptor. Glutamate is then cleared from the synaptic clefts by the Excitatory Amino Acid Transporter-2 (EAAT-2) and is recycled to glutamine by the astrocytes, which results in the functional compartmentalization of glutamate and glutamine [13] (Figure 1).

When ammonia levels rise quickly within the brain, the glutamine synthetase enzyme located in the astrocytes rapidly synthesizes glutamine from ammonia, causing an excess of glutamine production in the brain which can disrupt the symbiotic relationship between neurons and astrocytes [14]. Such changes result in alterations of the astrocytic volume and in increased extracellular concentrations of excitatory and inhibitory substances. The subsequent intracellular osmolarity increase can also cause astrocyte swelling and loss [15]. Besides astrocyte morphological changes, increased brain ammonia concentrations also alter the expression levels of astrocyte proteins such as glial fibrillary acidic protein, glutamate, glycine transporters, and "peripheral-types" benzodiazepine receptors [16]. As a result, inflammatory cytokines, including tumor necrosis factor- $\alpha$, interleukin-1, interleukin- 6 , and interferon, are released from the astrocytes [16]. Ammonia also can affect energy production mechanism in the astrocytes. Ammonia inhibits $\alpha$-ketoglutarate dehydrogenase or oxoglutarate dehydrogenase, and the depletion of carboxylic acids, which are used for glutamine synthesis, paralyzes the Krebs cycle. The production of adenosine $5^{\prime}$-triphosphate and nicotinamide adenine dinucleotide (reduced form) in the Krebs cycle is decreased, and pyruvate conversion to lactate is increased [17]. Elevated lactate levels in the astrocytes were related to the development of brain edema. The decreased expression of glutamate receptors in the astrocytes causes glutamate increase and, possibly, seizures. Moreover, cerebral blood flow increases, cerebral autoregulation is lost, and cerebral edema and intracranial hypertension (ICH) may develop [18]. 


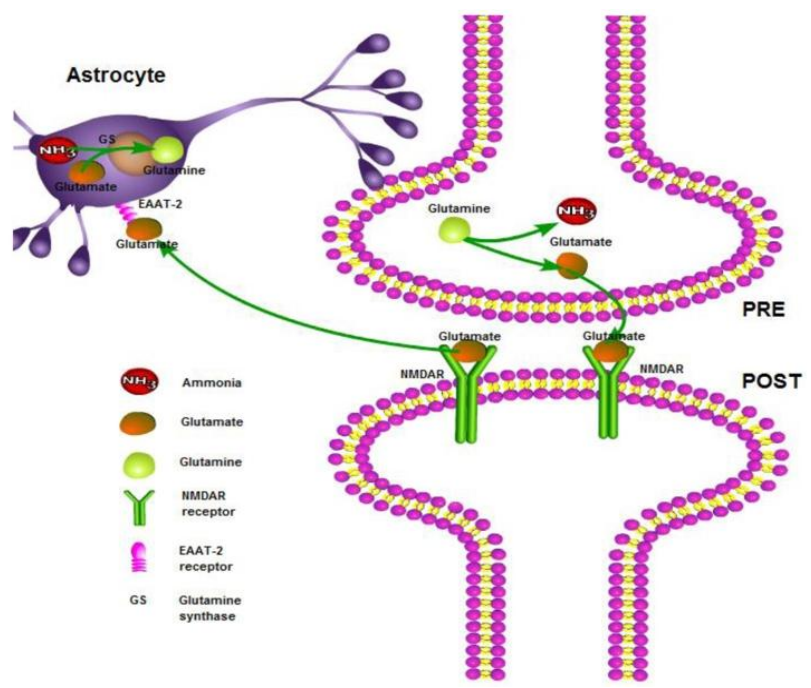

Figure 1. Ammonia removal by glutamine synthetase (GS) in astrocytes and the key steps in the "glutamate-glutamine cycle". Glutamate is released into the synaptic cleft from the presynaptic neuron (PRE), where it acts on the postsynaptic (POST) NMDAR receptor. The excess glutamate is then taken up by the astrocytes via the glutamate receptor EAAT-2.

\section{Current Treatments of Hyperammonemia}

The current therapeutic options to treat hyperammonemia target either the reduction of ammoniagenesis and its absorption in the gastrointestinal (GI) tract, or the activation of ammonia removal by upregulating ureagenesis through treatment with $N$-carbamylglutamate or supplementation of urea cycle intermediates and glutamine synthesis (Figure 2) [19]. First, we will cover the current standard treatment of hyperammonemia caused by both liver disease and inborn urea cycle disorder. Additionally, treatments that were promising in clinical trials and treatments that were tried but were not efficacious are also mentioned briefly (Table 1).

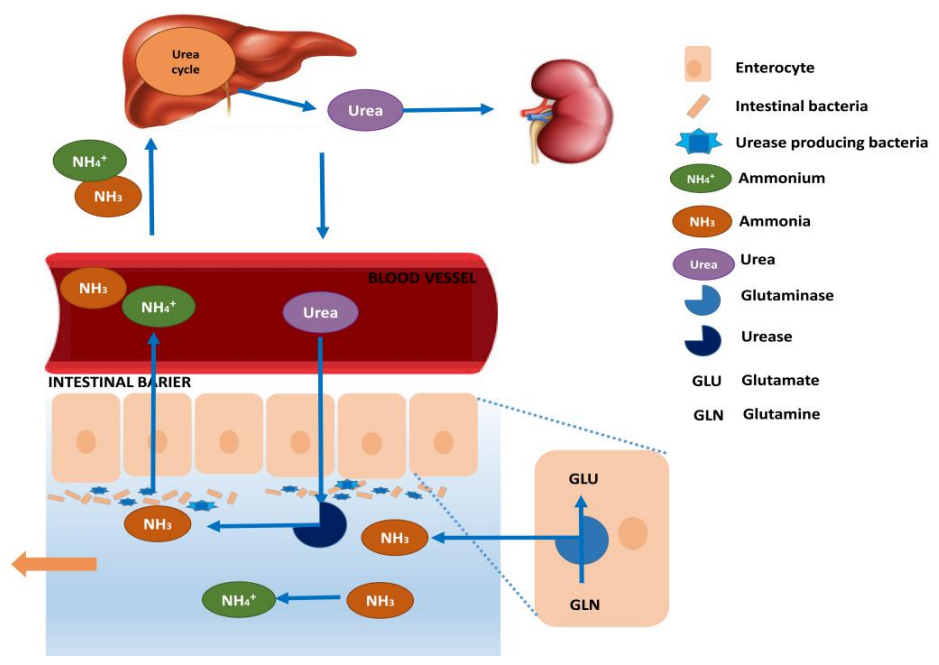

Figure 2. Ammonia trafficking between the liver and the gut. In the liver, ammonia detoxifies through the urea cycle and produces urea, which is excreted by the kidneys or transported to the intestine. Bacteria residing in the gastrointestinal tract produce urease and hydrolyze urea into carbon dioxide and ammonia. In addition, enterocytes of the small intestine and colon also produce ammonia through the deamination of glutamine by glutaminase. Gut-derived ammonia is then (i) utilized by the gut bacteria for protein synthesis; (ii) reabsorbed into the intestinal blood vessels, which are the main suppliers of the portal vein, to be pooled into the liver for endogenous detoxification; (iii) excreted in the feces. 
Table 1. Current treatments of hyperammonemia.

\begin{tabular}{|c|c|c|c|c|}
\hline Name of Medicines & Pharmaceutical Name & Mechanism of Action & Drawbacks & Ref. \\
\hline Lactulose $^{\mathrm{a}}$ & Enulose & $\begin{array}{l}\text { acidification of the colonic } \\
\text { contents, increase in osmotic } \\
\text { pressure, cathartic effect }\end{array}$ & $\begin{array}{c}\text { customized drug dosage, } \\
\text { abdominal cramping, bloating, } \\
\text { flatulence, electrolyte } \\
\text { imbalances }\end{array}$ & {$[20,21]$} \\
\hline Rifaximin $^{a}$ & Xifaxan & $\begin{array}{l}\text { inhibition of RNA synthesis in } \\
\text { intestinal bacteria }\end{array}$ & $\begin{array}{l}\text { high cost, nausea, bloating, } \\
\text { diarrhea, antibiotic resistance }\end{array}$ & {$[22,23]$} \\
\hline $\begin{array}{c}\text { Sodium } \\
\text { phenylacetate/ } \\
\text { phenylbutyrate }^{\text {a }}\end{array}$ & Bupenyl & $\begin{array}{l}\text { decrease glutamine degradation, } \\
\text { increase glutamine elimination }\end{array}$ & $\begin{array}{l}\text { complication for patients with } \\
\text { hypertension. }\end{array}$ & [26-28] \\
\hline $\begin{array}{l}\text { L-arginine a / } \\
\text { L-citrulline }^{\text {a }}\end{array}$ & L-arginine/L-citrulline & activation of UC & $\begin{array}{l}\text { gastrointestinal distress, } \\
\text { increase plasma citrulline, } \\
\text { diarrhea }\end{array}$ & {$[29,30]$} \\
\hline $\begin{array}{l}\text { Albumin-based } \\
\text { dialysis }^{\mathrm{a}}\end{array}$ & $\begin{array}{l}\text { Prometheus }{ }^{\circledR} \text {, Hepa } \\
\text { Wash }{ }^{\circledR}, \text { MARS }\end{array}$ & $\begin{array}{l}\text { elimination of albumin-bound } \\
\text { substances }\end{array}$ & mild thrombocytopenia & {$[34]$} \\
\hline Peritoneal dialysis ${ }^{a}$ & & $\begin{array}{c}\text { decrease of blood ammonia by } \\
\text { transporting ammonia from } \\
\text { vascular system to peritoneal } \\
\text { cavity }\end{array}$ & $\begin{array}{l}\text { mild to moderate nausea and } \\
\text { vomiting }\end{array}$ & {$[35,36]$} \\
\hline Neomycin ${ }^{b}$ & Neomycin & $\begin{array}{l}\text { inhibition of protein synthesis in } \\
\text { intestinal bacteria }\end{array}$ & oto-, neuro-, nephrotoxicity & [37] \\
\hline Metronidazole ${ }^{b}$ & Metronidazole & $\begin{array}{c}\text { inhibition of nucleic acid } \\
\text { synthesis in intestinal bacteria }\end{array}$ & oto-, neuro-, nephrotoxicity & {$[38,39]$} \\
\hline $\begin{array}{l}\text { L-ornithine/ } \\
\text { L-aspartate }^{\text {b }}\end{array}$ & $\begin{array}{l}\text { L-ornithine/ } \\
\text { L-aspartate }\end{array}$ & activation of UC & $\begin{array}{l}\text { severe stomach cramping and } \\
\text { diarrhea }\end{array}$ & [44-46] \\
\hline L-carnitine ${ }^{b}$ & L-carnitine & activation of UC & nausea, stomach discomfort & {$[47,48]$} \\
\hline $\begin{array}{l}\text { Branched-chain } \\
\text { amino acids } \\
\text { (BCAA) }^{b}\end{array}$ & & $\begin{array}{l}\text { decrease glutamine degradation, } \\
\text { increase glutamine elimination }\end{array}$ & increase of blood ammonia & {$[49,50]$} \\
\hline $\begin{array}{l}\text { Bioartificial liver } \\
\text { support systems }^{c}\end{array}$ & $\begin{array}{l}\text { AMC bioartificial } \\
\text { liver }^{\circledR}, \text { Excorp }^{\circledR} \\
\text { HepatAssist }^{\circledR}\end{array}$ & $\begin{array}{l}\text { support for liver metabolic } \\
\text { activity }\end{array}$ & $\begin{array}{l}\text { a minor decrease in arterial } \\
\text { ammonia, bleeding }\end{array}$ & {$[51,52]$} \\
\hline $\begin{array}{l}\text { Liver cell } \\
\text { transplantation }{ }^{c}\end{array}$ & & activation of UC & $\begin{array}{l}\text { portal vein thrombosis, } \\
\text { shunting of liver cells into the } \\
\text { systemic circulation, scarcity of } \\
\text { donor organs }\end{array}$ & [53-55] \\
\hline $\begin{array}{l}\text { Stem cell } \\
\text { transplantation }\end{array}$ & HepaStem ${ }^{\circledR}$ & activation of UC & $\begin{array}{l}\text { short time efficiency, } \\
\text { autoimmune reaction }\end{array}$ & {$[56-58]$} \\
\hline $\begin{array}{l}\text { Adenovirus } \\
\text { associated gene } \\
\text { delivery }^{c}\end{array}$ & $\begin{array}{c}\text { Ornithine } \\
\text { transcarbamoylase/ } \\
\text { Arginase } 1 \text { gene } \\
\text { delivery }\end{array}$ & activation of UC & $\begin{array}{c}\text { safety problem of the viral } \\
\text { delivery system, short- time } \\
\text { efficiency }\end{array}$ & {$[59,60]$} \\
\hline
\end{tabular}

\section{UC: urea cycle; ${ }^{a}$ Standard therapeutic agents; ${ }^{b}$ Alternative therapeutic agents; ${ }^{c}$ Therapeutical agents} under investigation.

\subsection{Standard Therapeutic Agents for Hyperammonemia}

Non-absorbable disaccharides are the first-line therapy for patients with hyperammonemia [20]. The best example is lactulose consisting of the monosaccharides fructose and galactose. Lactulose is completely metabolized into lactic acid, formic acid, and acetic acid in the colon by ß-galactosidase 
from colonic bacteria, causing acidification in the colon and an increase of the osmotic pressure. The colonic acidic environment caused by lactulose metabolism inhibits the growth of urease-active bacteria while supporting acid-resistant, non-urease bacterial growth [61]. The increase of the osmotic pressure causes the cathartic effect and draws out ammonia from the body before it is absorbed [20,21]. However, lactulose has been shown to cause serious adverse effects, including abdominal cramping, flatulence, bloating, electrolyte imbalance, and it is difficult to decide the dosage in clinical treatment.

Rifaximin has become the most effective antibiotic of choice in the treatment of hyperammonemia because of its safety, efficacy, and tolerability [62]. Rifaximin is a nonsystemic, GI site-specific antibiotic as a result of the addition of a nonabsorbable pyridoimidazole ring. However, it retains the potential to cross the cell wall of Gram-negative bacteria and inhibits RNA synthesis by binding to the $\beta$ subunit of the bacterial DNA-dependent RNA polymerase enzyme [63] The beneficial effects of rifaximin in hyperammonemia treatment have been shown by several clinical trials $[22,23,64]$. However, the risk of accumulation was raised for HE patients with liver cirrhosis because only a small fraction of rifaximin is eliminated by the liver. The most common adverse reactions of rifaximin are nausea, bloating, and diarrhea [65].

Sodium benzoate decreases the blood ammonium level by reducing glycine metabolism in the liver, kidney, and brain. Benzoate integrates with coenzyme A (CoA) to form benzoyl-CoA in hepatocyte mitochondria. Then, benzoyl-CoA transfers the benzoyl moiety of the CoA ester to glycine and produces hippurate. This process hampers the degradation of glycine by the ammonia-forming metabolic pathway in the liver, kidney, and brain $[24,25,66]$.

Sodium phenylacetate/phenylbutyrate is rapidly oxidized to phenylacetate, which conjugates with glutamine in the liver and then is excreted as a phenylacetylglutamine by the kidneys. While phenylacetate significantly increases the urinary production of phenylacetylglutamine, it prevents glutamine-stimulated ammoniagenesis [26,67]. A recent study has suggested a novel pathway in which phenylacetate conjugates with glycine precluding glycine-derived ammonia [27]. The oral administration of sodium phenylacetate or phenylbutyrate might cause complications to hypertension patients derived from exceeding daily sodium uptake [28].

A combination therapy of sodium benzoate and sodium phenylacetate decreases plasma ammonia levels and contributes to the high survival rate in urea-cycle-disorder (UCD) patients with acute hyperammonemia, with an acceptable adverse effect profile consisting of headache, nausea, and impaired mental status [68].

L-Arginine and L-citrulline are a main and an intermediate product in the urea cycle (UC), respectively. L-arginine increases ammonia elimination by increasing L-citrulline and argininosuccinate production $[29,30]$. L-citrulline administration restores L-arginine levels in $N$-acetylglutamate synthetase and carbamoyl phosphate synthetase-1 deficiencies and supports the urea cycle [30]. L-arginine or L-citrulline administration is essential in UCDs to reactivate UC and reduce blood ammonium levels; however, the main drawback is the acute GI bleeding in cirrhotic patients [69].

Carglumic acid is a synthetic structural analog of $N$-acetylglutamate (NAG) that activates carbamoyl phosphate synthetase 1 (CPS-1) in the urea cycle that is responsible for the removal of ammonia. Its administration is essential in patients with an inherent deficiency of NAG synthase [31-33]. As an important cofactor for CPS-1, N-carbamylglutamate (NCG) can be used for partial CPS-1 deficiency patients to stimulate the remaining CPS-1 [70]. NCG administration for neonatal hyperammonemia caused by inborn metabolic disorders, such as propionic and methylmalonic acidemia, has been shown to be effective in ammonia reduction in case studies [32,71]. Propionic acid and methylmalonic acid inhibit NAG synthesis, which causes CPS-1 deficiency, the first enzyme in the urea cycle [72]. However, administration of NCG activated urea synthesis and reduced blood ammonia and glutamine [73].

Albumin-based dialysis (ABD) is considered as a regular part of treatment in intensive care medicine, especially for acute liver failure [34]. Albumin-based dialysis systems include both membrane and adsorption technology, consisting in blood dialysis against albumin-coated membranes 
and then against albumin-rich solutions, followed by adsorption on columns to remove water-soluble and albumin-binding toxic agents [74]. The modalities of the dialysis-based treatment significantly improved serum ammonia level in acute liver failure patients [75-77].

Peritoneal dialysis is an intracorporeal dialysis technique that uses the peritoneal membrane as a filter. The semipermeable peritoneal membrane allows solutes and water to be transported from the vascular system to the peritoneal cavity [35]. Although extracorporeal dialysis is more effective than peritoneal dialysis, it still is an effective treatment for the hyperammonemia caused by inborn UC errors, because of its quick and easy settings when a fast intervention is crucial $[36,78,79]$.

\subsection{Alternative Therapeutic Agents}

Many drugs have been used for the treatment of hyperammonemia, but data to support their use are limited. However, most of these drugs can safely be used despite their limited proven efficacy.

Neomycin and metronidazole have been historically used in the setting of hyperammonemia caused by liver disease [80]. Antibiotics administration has been suggested to inhibit the urease-producing bacterial growth in the gut, thus decreasing ammonia production and preventing its absorption through the GI tract. Neomycin is an aminoglycoside antibiotic that binds to the $30 \mathrm{~S}$ ribosomal subunit and inhibits the synthesis of proteins vital for bacterial growth [37]. However, its clinical use has waned because of its serious adverse effects, including oto-, neuro-, and nephrotoxicity following systemic exposure [81]. Metronidazole, a selective antimicrobial agent for anaerobic bacteria, has been found as effective as neomycin, because of its capability to bind to DNA and inhibit bacterial nucleic acid synthesis resulting in bacterial cell death. However, long-term use of metronidazole is limited because of its adverse effect [38,39].

Glycerol phenylbutyrate is a prodrug that is gradually hydrolyzed by pancreatic lipases, resulting in the delayed release of phenylbutyrate (PBA) in the GI tract. PBA undergoes $\beta$-oxidation to phenylacetate (PAA), which is conjugated with glutamine in the liver and the kidney through the enzyme phenylacetyl-CoA: L-glutamine- $N$-acetyltransferase to form phenylacetylglutamine (PAGN) and is released by the kidney [67]. Glycerol phenylbutyrate successfully lowered plasma ammonia in patients suffering from HE and it promises to be more suitable for hypertension patients $[40,41]$.

L-ornithine phenylacetate contains both L-ornithine and phenylacetate in a salt form that activates the urea cycle (UC) in the liver [42,43]. In the normal state, L-ornithine acts as a substrate for glutamine synthetase, thereby detoxifying ammonia into glutamine. Then, phenylacetate binds to excessive glutamine to make phenylacetate glutamine, which can be secreted by the kidneys. However, L-ornithine or phenylacetic acid alone cannot effectively treat $\mathrm{HE}$, whereas phenylacetate-L-ornithine can effectively reduce intestinal glutaminase activity and its expression by improving the intestinal synthesis of glutamine, thereby reducing the brain arterial ammonia levels and extracellular ammonia in animal models $[82,83]$. The intravenous administration of L-ornithine phenylacetate in cirrhotic patients induced a reduction of plasma ammonia and glutamine levels with a gradual increment in urinary phenylacetylglutamine [84].

L-Ornithine-L-aspartate fuels the ammonia-detoxifying metabolic pathway in the residual hepatocytes. The residual hepatocytes are the precursor liver cells that can generate a new generation of hepatocytes on physiological demand to increase the functional capacity of the liver. L-Ornithine is transformed to glutamate semialdehyde by ornithine aminotransferase, which is subsequently converted to glutamate. Finally, glutamate converts to glutamine, which detoxifies one ammonia molecule by glutamine synthetase [44,85]. The intravenous and oral administration of L-ornithine-L-aspartate successfully improved venous ammonia levels and cognitive abilities in HE patients $[45,46]$. However, a clinical trial in patients with acute liver failure did not show any improvement of the arterial ammonia levels compared to a standard treatment [86].

L-Carnitine, a metabolic product of amino acids, activates UC enzymes and increases the elimination of free radicals by participating in the transportation of short-chain fatty acids through the 
peroxisomal and mitochondrial membranes [47]. A treatment with L-carnitine significantly reduced blood ammonia and improved patient mental status [48,87].

BCAAs (branched-chain amino acids) such as valine, leucine, and isoleucine interact with $\alpha$-ketoglutarate through branched-chain aminotransferases and form glutamate and branched-chain $\alpha$-keto acid. Glutamate converts to glutamine by incorporating an ammonia molecule through glutamine-synthetase [49]. However, BCAA administration led to increased blood ammonia in both healthy and cirrhosis patients because of the activation of muscle ammonia metabolism [50].

\subsection{Therapeutic Agents under Investigation}

Bioartificial liver support systems are model systems that recapitulate the liver metabolic activity. They are similar to the conventional hemodialysis with the addition of filtration through multiple hollow-fiber cartridges which contain cells with hepatocytic functions, such as the VTL C3A cell line [51]. In a controlled clinical trial, bioartificial liver systems showed effectiveness in acute liver failure patients, but arterial ammonia failed to show significant changes compared to the control group [52].

Cell therapy might be an appropriate strategy to transfer the missing enzymes via liver cell transplantation in UCD [53]. Liver hepatocytes were cultured from the liver parenchymal cell fraction of a donor and transplanted into a neonate with a diagnosis of ornithine transcarbamylase deficiency (OTCD). After transplantation, protein intolerance was improved, and no metabolic crises were observed. Another similar trial showed that the laboratory parameters were improved only slightly, possibly because of the rejection of the transplanted cells resulting from insufficient immunosuppression [54,55]. However, the availability of hepatocytes is limited by the scarcity of available livers, and therefore the use of stem cells is under investigation. Hematopoietic stem cells, adipose-derived stem cells, amniotic epithelial cells, and umbilical cord blood cells are being considered as a suitable candidates for hepatic stem cells transplantation because of their capability to proliferate and differentiate into hepatocyte-like cells in vivo [56]. However, the delivery approach and a sufficient quantity of cells to improve the clinical phenotypes of the patients are still not clear $[57,58]$.

Gene therapy which introduces a functional enzyme-coding gene promises to restore UC activity in patients with primary UCD. The delivery of the ornithine transcarbamoylase and arginase 1 gene via an adeno-associated virus vector resulted in successful phenotype correction in mouse models, while the safety of the gene delivery system and its long-term effectiveness for human trails has been challenging $[59,60,88]$.

\section{Future Direction to Manage Hyperammonemia: Pharmabiotic Approaches}

The GI system has a close association with the liver, known as the gut-liver axis. Gut microbiota metabolic products are absorbed through the intestinal wall in the portal vein and then are transported to the liver for filtration and detoxification. In turn, the liver secretes bile acids which are stored and concentrated in the gall bladder, which secretes the acids into the intestine modulating its activities. The gut, especially in the large intestine, contains large numbers of microorganisms. The number of microorganism cells is about equal or greater compared to the number of cells of the host $[89,90]$. Almost 300 to 500 different kinds of species reside in the gut. According to Neish's study, $10^{9}$ colony forming units $(\mathrm{CFU}) / \mathrm{mL}$ and $10^{12} \mathrm{CFU} / \mathrm{mL}$ of bacteria may be found in the terminal ileum and colon [91]. The intestinal bacteria play an important role in human health, such as by supplying essential nutrients, synthesizing vitamin $\mathrm{K}$, aiding in the digestion of cellulose, and promoting angiogenesis and enteric nerve function [92]. A significant alteration in the types and amounts of microorganisms affect the ammonia production and function of the intestinal immune system. Since ammonia can move through the intestinal lumen and body fluid, the removal of intestinal ammonia by gut microbial species such as Lactobacillus species could reduce blood ammonia levels and improve health. Current pharmabiotic approaches are shown in (Table 2). 
Table 2. Investigational pharmabiotic approaches for hyperammonemia treatment.

\begin{tabular}{|c|c|c|c|c|}
\hline & Bacterial Species & Mechanism of Action & Approved Indication & Ref. \\
\hline \multirow[t]{4}{*}{ Probiotic } & Lactobacillus Plantarum & $\begin{array}{c}\text { Direct Ammonia Consumption in } \\
\text { the Gut }\end{array}$ & $\begin{array}{l}\text { increase the survival rate of mice and } \\
\text { decreased blood and fecal ammonia } \\
\text { concentration in acute or chronic liver } \\
\text { failure, a decrease of astrocyte } \\
\text { swelling in the brain cortex in the } \\
\text { acute liver failure mice model }\end{array}$ & [93] \\
\hline & Lactobacillus acidophilus & modify the intestinal flora & $\begin{array}{l}\text { treat MHE in liver cirrhosis and } \\
\text { improvement in cognitive } \\
\text { performance }\end{array}$ & [95] \\
\hline & $\begin{array}{l}\text { Lactobacillus rhamnosus GG } \\
\text { (LGG) }\end{array}$ & $\begin{array}{l}\text { LGG has the ability to attach to the } \\
\text { intestinal mucosa and promote } \\
\text { epithelial function against the } \\
\text { pathogens and promote other } \\
\text { beneficial microbiota and stimulate } \\
\text { the host immune system through } \\
\text { soluble molecule crosstalk }\end{array}$ & $\begin{array}{l}\text { reduction in endotoxemia and } \\
\text { reduction in gut dysbiosis with } \\
\text { improved gut } \\
\text { microbiome-metabolome linkages }\end{array}$ & [97] \\
\hline & $\begin{array}{l}\text { Lactobacillus plantarum } \\
\text { NCU116 }\end{array}$ & $\begin{array}{l}\text { downregulating lipogenesis and } \\
\text { upregulating lipolysis and fatty } \\
\text { acid oxidation-related gene } \\
\text { expression }\end{array}$ & $\begin{array}{l}\text { improving liver function, oxidative } \\
\text { stress and lipid metabolism }\end{array}$ & [98] \\
\hline
\end{tabular}

MHE: minimal hepatic encephalopathy.

\subsection{Probiotic and Synbiotic Approaches}

Probiotics are intended to affect the host's health beneficially. The most common probiotic strains are lactic acid bacteria, including Lactobacilli, Lactococcus lactis, Streptococcus, and Bifidobacteria, or yeasts such as Saccharomyces cerevisiae. Enterococcus, Pediococcus, Leuconostoc, Bacillus, and Escherichia coli can also be used as probiotic strains. Probiotics are used commonly as biological components in many functional fermented foods, and the most important synergy of all probiotic species appears to be the fermentation of unabsorbed sugar. Probiotics also have antimicrobial activities because the production of antimicrobial compounds such as bacteriocin and nisin inhibits the pathogens. In addition, probiotics have a role in reducing the total amount of ammonia in the portal blood because probiotics inhibit bacterial urease activity, which may be due to lactic acid [100,101]. Probiotics also decrease intestinal permeability and bacterial urease secretion, increase ammonia excretion, and improve the nutritional status of the gut epithelium cells. As most probiotics produce acids that reduce the $\mathrm{pH}$ in the intestine, ammonia absorption also decreases. In addition, probiotics reduce inflammation and oxidative stress in liver cells, which leads to increased hepatic clearance of ammonia and reduced uptake of other toxins. It has been reported that oral ingestion of specific probiotics can be used to promote the growth of non-urease-producing bacteria in cirrhotic patients and to reverse the imbalance of coliforms microorganisms seen in cirrhosis [102]. After three months, probiotics appeared 
to reduce plasma ammonia levels in $\mathrm{HE}$ patients by an average of $7 \mu \mathrm{mol} / \mathrm{L}$, especially in a long-term treatment [103]. However, in clinical practice, there is a lack of accurate evidence of improvements regarding the recovery rate, mortality rate, and length of patient's hospital stay [103].

In Charles Nicaise and Deborah Prozzi's work, Sparse-fur mice were used as a constitutive hyperammonemia model, and, in the chronic hepatic-insufficient mice model, ammonia was efficiently decreased by Lactobacillus plantarum administration [93]. In a murine thioacetamide-induced acute liver failure model, probiotics significantly increased the survival rate of mice and decreased blood and fecal ammonia concentration [93]. A strain that hyperconsumes ammonia was constructed by inactivation of lactate dehydrogenase (LDH) and by alanine dehydrogenase (AlaD) gene knock-in [93,104]. This hyperconsuming strain is able to use ammonia via AlaD, which converts pyruvate to alanine, while the LDH inactivation can prevent pyruvate transformation into lactate. This hyperconsuming strain showed enhanced efficacy compared to its wild-type counterpart at a lower dose in treating hyperammonemia [104]. In the acute liver failure mice model, lower blood ammonia levels improved the survival rate and reduced astrocyte swelling in the brain cortex. The modulation of ammonia was abolished after administration of the strain deficient in the ammonium transporter AmtB [93,105]. This research showed that the probiotic strain L. plantarum contributes to ammonia reduction by direct consumption of ammonia rather than by alteration of the environment in the intestine [93].

It is well known that chronic hyperammonemia (HA) can induce cognitive decline and anxiety-like behavior in a rat model, demonstrating that HA-mediated HE can cause neurological dysfunctions. Furthermore, the treatment with the probiotic strain Lactobacillus helveticus NS8 can improve cognitive decline and anxiety-like behavior in HA rats, suggesting that this probiotic strain can be used for the treatment of neurological dysfunctions in HA rats [94]. From previous research, it was shown that Lactobacillus acidophilus administration could be used to treat hepatic encephalopathy by modifying the intestinal flora [95]. Also, Enterococcus faecium SF68 was used in the long-term treatment of patients with cirrhosis and grade 1-2 hepatic encephalopathies [96]. Probiotics alter the composition of the gut microbiota as well as certain markers of inflammation [97], probably because probiotics adhere to the gut tissue and interact with the host, thereby inhibiting the infection with pathogens [106]. Another recently discovered Gorbach-Goldin strain, a probiotic strain of GG called Lactobacillus rhamnosus, was safe for patients with low-grade HE in a phase I study, while self-limiting diarrhea was reported [97]. It was also reported that in non-alcoholic fatty liver disease (NAFLD) rat models, Lactobacillus plantarum NCU116 can restore liver function, decrease oxidative stress, and decrease liver fat accumulation levels [98]. A number of intestinal strains, including Lactobacillus acidophius JBD401, were also identified showing rapid ammonia removal from the blood as well as the brain, thus having neuroprotective efficacy in vivo in animal models (unpublished data).

Since several probiotic strains have the ability to treat diseases associated with hyperammonemia, it was also reported that highly concentrated combinations of probiotic strains have a more significant effect on the treatment of HE patients [107]. The VSL \#3 formula (Sigma-Tau Pharmaceuticals, Pomezia, Italy) contains eight lactic acid bacteria (Lactobacillus, Bifidobacterium and Streptococcus thermophilus), selected specifically for their ability to reduce inflammation and reduce intestinal permeability. Each hydroxypropyl methylcellulose capsule of VSL \#3 contains a high number of live freeze-dried probiotic bacteria (110 billion) that are constituents of the normal GI flora of healthy humans [108]. A considerable fraction of the bacterial components of VSL \#3 seems to remain viable during the passage through the GI tract until it reaches the colon [109]. Two phase II/III randomized controlled trials showed that VSL \#3 significantly reduced arterial blood ammonia levels, improved clinical symptoms, and reduced the risk of HE compared with the placebo [99]. In addition, VSL \#3 is undergoing a clinical endpoint study (stage IV; cognitive, risk of falls, and quality of life; NCT01686698). VSL \#3 is also used in lower-grade HE children due to portal hypertension caused by portal vein thrombosis (Phase III, NCT01798329).

Synbiotic supplementation, which contains the lyophilized non-urease-producing bacteria Pediococcus pentosaceus, Leuconostoc mesenteroides, Lactobacillus plantarum 2592, and Lactobacillus paracasei 
subsp. paracasei 19 , each at a dose of $10^{10} \mathrm{CFU}$ per sachet, along with 10 grams of biologically active fermentable fibers consisting of inulin, pectin, beta-glucan, and resistant starch, can be used to treat cirrhosis patients with minimal $\mathrm{HE}$, leading to a significant reduction in the number of urease-producing bacteria such as E. coli, Staphylococcus, and Fusobacterium sp. In contrast, no-urease-producing Lactobacillus sp. increased significantly, becoming the predominant creature in the stool [100]. The synbiotic treatment can significantly modify the gut flora and decrease gastrointestinal $\mathrm{pH}$, which has a significant impact on the bacterial flora, vitamins and electrolytes absorption, and digestive enzymes activity [110]. The regulation of the intestinal microflora effectively reduces blood ammonia levels, reversing 50\% of minimal hepatic encephalopathy (MHE) patients. Significant reductions in endotoxemia have also been associated with a synbiotic treatment [100]. Moreover, synbiotics may reduce the incidence of pathogens by affecting the pathogenic parenteral translocation in the intestinal flora of cirrhotic patients [111].

\subsection{Gut Microbiota-Based Approaches}

Current therapies for hyperammonemia treatments, involving rifaximin, lactulose, and probiotics, focus on the intestinal ecosystem and indeed have variable effects on the composition and function of the intestinal microbiota [112]. Therefore, the current standard treatment has already incorporated the modulation of the gut microbiota in the basic therapeutic treatment of hyperammonemia. Increasing evidence showed that the gut microbiota could be altered to benefit the host or to prevent disease states. Thus, the modification of the host metabolism by engineering the gut microbiota provides a new therapeutical treatment approach for hyperammonemia [113].

Ammonia can be produced by the urease that hydrolyzes urea into carbon dioxide and ammonia [114]. As it is well known, the mammalian genomes do not encode urease genes, and thus ammonia production resulting from the urease-producing bacteria acts on the host system. Urease-producing bacteria are frequently gram-negative Enterobacteriaceae but maybe anaerobes or gram-positive bacteria. In healthy conditions, the activity of urease from urease-producing bacteria is normally beneficial for the hosts. In the presence of liver diseases, however, it is very pathogenic to the hosts. Urea produced by the liver as a waste product is both excreted by the kidneys in urine and transported into the colon [115]. In unhealthy hosts with liver injury, chronic liver disease, or urea cycle defects, the ammonia levels are elevated because the ammonia delivered to the liver from the GI tract cannot normally be processed because of the hepatic damage. Therefore, most of the treatments for HE have targeted these colonic urease-producing bacteria [116]. The circulating ammonia levels are also correlated with damage to the CNS in patients with chronic liver disease or inborn metabolism errors resulting in hepatic encephalopathy (HE) [117].

It was observed that the microbiome was altered in liver diseases (Table 3), and this presents opportunities for potential fecal transplantation therapy [102]. However, the microbial population of patients with cirrhosis due to HE has been shown to be enriched in the rich families of Fusarium and Enterobacteriaceae, as well as in the abundant primary taxa of the Ruminococcaceae, Lachnospiraceae, and Clostridia strains, compared with that of healthy individuals. Recent studies have shown that the cirrhosis dysbiosis ratio (CDR) is positively correlated with cirrhosis, as calculated by quantifying fecal bacterial strain counts in a control group, in patients with compensated cirrhosis, and in patients with decompensated cirrhosis. The lower CDR indicates a less diverse gut microbial composition and is associated with increased scores in the model for end-stage liver disease (MELD) and with increased intestinal permeability [118]. Decompensated cirrhotic patients with hepatic encephalopathy had a more reduced gut microbial diversity compared to cirrhotic patients [119]. 
Table 3. Changes in the gut microbiota associated with hyperammonemia-related disease.

\begin{tabular}{|c|c|c|c|c|c|c|}
\hline Comparison $^{a}$ & \multicolumn{3}{|c|}{ Microbiota } & Sample & Methodology & Ref. \\
\hline $\begin{array}{l}\text { Liver cirrhosis with HE } \\
\text { vs. Healthy control }\end{array}$ & & $\begin{array}{c}\text { Streptococcaceae } \uparrow \\
\text { Veillonellaceae } \uparrow\end{array}$ & $\begin{array}{c}\text { Streptococcus } \uparrow \\
\text { Streptococcus } \\
\text { salivarius } \uparrow\end{array}$ & stool & $\begin{array}{l}\text { 16S rRNA gene } \\
\text { pyrosequencing }\end{array}$ & [120] \\
\hline $\begin{array}{l}\text { Liver cirrhosis vs. } \\
\text { Healthy control }\end{array}$ & $\begin{array}{c}\text { Bacteroidetes } \downarrow \\
\text { Proteobacteria } \uparrow \\
\text { Fusobacteria } \uparrow\end{array}$ & $\begin{array}{c}\text { Lachnospiraceae } \downarrow \\
\text { Enterobacteriaceae } \uparrow \\
\text { Veillonellaceae } \uparrow \\
\text { Streptococcaceae } \uparrow\end{array}$ & & stool & $\begin{array}{l}\text { 16S rRNA gene } \\
\text { pyrosequencing }\end{array}$ & [121] \\
\hline $\begin{array}{l}\text { Liver cirrhosis vs. } \\
\text { Healthy control }\end{array}$ & $\begin{array}{c}\text { Bacteroidetes } \downarrow \\
\text { Proteobacteria } \uparrow \\
\text { Fusobacteria } \uparrow\end{array}$ & & $\begin{array}{c}\text { Bacteroides } \downarrow \\
\text { Veillonella } \uparrow \\
\text { Streptococcus } \uparrow \\
\text { Clostridium } \uparrow \\
\text { Prevotella } \uparrow\end{array}$ & stool & $\begin{array}{l}\text { 16S rRNA gene } \\
\text { pyrosequencing }\end{array}$ & [122] \\
\hline $\begin{array}{l}\text { Liver cirrhosis with HE } \\
\text { vs. Liver cirrhosis } \\
\text { without HE }\end{array}$ & & $\begin{array}{c}\text { Ruminococcaceae } \downarrow \\
\text { Veillonellaceae } \uparrow \\
\text { Porphyromonadaceae } \uparrow \\
\text { Alcaligeneceae } \uparrow \\
\text { Enterobacteriaceae } \uparrow \\
\text { Fusobacteriaceae } \uparrow\end{array}$ & & stool & $\begin{array}{c}\text { Multitag } \\
\text { pyrosequencing }\end{array}$ & [123] \\
\hline $\begin{array}{l}\text { Liver cirrhosis with HE } \\
\text { vs. Healthy control }\end{array}$ & & $\begin{array}{c}\text { Lachnospiraceae } \downarrow \\
\text { Ruminococcaceae } \downarrow \\
\text { Alcaligeneceae } \uparrow \\
\text { Enterobacteriaceae } \uparrow \\
\text { Fusobacteriaceae } \uparrow\end{array}$ & & stool & $\begin{array}{c}\text { Multitag } \\
\text { pyrosequencing }\end{array}$ & [123] \\
\hline $\begin{array}{l}\text { Liver cirrhosis with HE } \\
\text { vs. Healthy control }\end{array}$ & & $\begin{array}{c}\text { Burkholderiaceae } \uparrow \\
\text { Streptomycetaceae } \uparrow \\
\text { Incertae Sedis XIV } \downarrow \\
\text { Lachnospiraceae } \downarrow \\
\text { Ruminococcaceae } \downarrow \\
\text { Ruminococcaceae } \downarrow\end{array}$ & $\begin{array}{c}\text { Burkholderia } \uparrow \\
\text { Streptomyces } \uparrow \\
\text { Blautia } \downarrow \\
\text { Roseburia } \downarrow \\
\text { Faecalibacterium } \downarrow \\
\text { Subdoligranulum } \downarrow\end{array}$ & $\begin{array}{l}\text { mucosal } \\
\text { sample }\end{array}$ & $\begin{array}{c}\text { Multitag } \\
\text { pyrosequencing }\end{array}$ & [123] \\
\hline
\end{tabular}

HE, hepatoencepalophaty; ${ }^{a}$ A compariaon of condition A vs. condition B; $\uparrow$, increase in condition A related to condition $\mathrm{B} ; \downarrow$, decrease in condition A related to condition B.

Evidence suggests that fecal transplantation may have a therapeutic effect on the disease by altering the microorganisms bringing them close to their normal composition. In Ting-Chin David Shen's study with mice inoculated with a slurry of bacteria with low urease gene activity via fecal transplantation, ammonia concentration in the feces was significantly reduced [124]. The altered Schaedler flora (ASF) is a community of eight bacterial species: Parabacteroides (strain ASF519), Lachnospiraceae (strain ASF502), Ruminococcaceae (strain ASF500), Eubacterium (strain ASF492), Mucispirillum (strain ASF457), L. salivarius (strain ASF361), L. acidophilus (strain ASF360), and Clostridium (strain ASF356). The bacteria were selected because of their dominance and persistence in the normal microflora of mice and also because this consortium of eight bacteria has the minimal urease gene content [125]. The animals were depleted of their preexisting gut microbiota by using antibiotics and then inoculated with ASF. Within several months after the ASF transfer, a substantial number of non-ASF taxa were increased. There was no return of urease activity, demonstrating that this protocol can be used to establish a persistent new community and have a long-term reduction in fecal urease activity and ammonia production. Moreover, in the hepatic injury murine model, ASF transplantation also decreased morbidity and mortality [124]. These results provide a new therapeutic 
possibility consisting in the treatment of the host with antibiotics, followed by the inoculation of a defined gut microbiota to have a durable metabolic effect [114].

\section{Conclusions and Perspective}

Hyperammonemia is a disease of metabolic disturbances resulting from an excess amount of ammonia in the blood. Although the immediate consequence of hyperammonemia is to cause encephalopathy and death, a prolonged, low-degree hyperammonemia might be related to neurodegenerative diseases such as Alzheimer's disease, Parkinson's diseases, etc. [126]. Therefore, the maintenance of low blood levels of ammonia would be important not only to treat hyperammonemia but also to prevent or slow down the development of neurodegenerative diseases. The current pharmaceutical approaches to lower blood ammonia levels do not provide a satisfactory solution in terms of efficacy and side effects. Recent evidence, however, suggests that pharmabiotic approaches using probiotics or directly modifying the gut microbiota cast a light on the development of a revolutionary therapy for hyperammonemia $[113,120]$. We believe that developing the gut microbiota as pharmabiotics to treat hyperammonemia and its related diseases should be actively explored to provide an ideal pharmaceutical solution for hyperammonemia.

Acknowledgments: This research was financially supported by the "Global accompanied growth R\&BD program (N042600010)" through the Ministry of Trade, Industry and Energy (MOTIE, Korea).

Author Contributions: Jing Liu and Enkhchimeg Lkhagva equally contributed to writing the manuscript. Hyeon-Jin Kim critically reviewed the manuscript. Seong-Tshool Hong supervised the whole process and reviewed the manuscript. All authors approved the final version of the manuscript.

Conflicts of Interest: The authors declare no conflict of interest.

\section{References}

1. Bachmann, C. Mechanisms of hyperammonemia. Clin. Chem. Lab. Med. 2002, 40, 653-662. [CrossRef] [PubMed]

2. Weiner, I.D.; Mitch, W.E.; Sands, J.M. Urea and ammonia metabolism and the control of renal nitrogen excretion. Clin. J. Am. Soc. Nephrol. 2015, 10, 1444-1458. [CrossRef] [PubMed]

3. Norenberg, M.D.; Rao, K.V.; Jayakumar, A.R. Mechanisms of ammonia-induced astrocyte swelling. Metab. Brain Dis. 2005, 20, 303-318. [CrossRef] [PubMed]

4. Ott, P.; Vilstrup, H. Cerebral effects of ammonia in liver disease: Current hypotheses. Metab. Brain Dis. 2014, 29, 901-911. [CrossRef] [PubMed]

5. Machado, M.C.; da Silva, F.P. Hyperammonemia due to urea cycle disorders: A potentially fatal condition in the intensive care setting. J. Intensive Care 2014, 2, 22. [CrossRef] [PubMed]

6. Butterworth, R. Effects of hyperammonaemia on brain function. J. Inherit. Metab. Dis. 1998, 21, 6-20. [CrossRef] [PubMed]

7. Schror, K. Aspirin and Reye syndrome: A review of the evidence. Paediat. Drugs 2007, 9, 195-204. [CrossRef]

8. Hook, S.A. The gale encyclopedia of neurological disorders. Ref. User Serv. Q. 2005, 44, 341-343.

9. Committee, P.F. British National Formulary for Children 2014-2015, 1st ed.; Pharmaceutical Press: London, UK, 2014.

10. Bosoi, C.R.; Rose, C.F. Identifying the direct effects of ammonia on the brain. Metab. Brain Dis. 2009, 24, 95-102. [CrossRef] [PubMed]

11. Solga, S.F. Probiotics can treat hepatic encephalopathy. Med. Hypotheses 2003, 61, 307-313. [CrossRef]

12. Weiner, I.D.; Verlander, J.W. Renal ammonia metabolism and transport. Compr. Physiol. 2013. [CrossRef]

13. Cagnon, L.; Braissant, O. Hyperammonemia-induced toxicity for the developing central nervous system. Brain Res. Rev. 2007, 56, 183-197. [CrossRef] [PubMed]

14. Shawcross, D.; Jalan, R. The pathophysiologic basis of hepatic encephalopathy: Central role for ammonia and inflammation. Cell. Mol. Life Sci. 2005, 62, 2295-2304. [CrossRef] [PubMed]

15. Ziada, D.H.; Soliman, H.H.; El Yamany, S.A.; Hamisa, M.F.; Hasan, A.M. Can Lactobacillus acidophilus improve minimal hepatic encephalopathy? A neurometabolite study using magnetic resonance spectroscopy. Arab J. Gastroenterol. 2013, 14, 116-122. [CrossRef] [PubMed] 
16. Zieve, L. Pathogenesis of hepatic encephalopathy. Metab. Brain Dis. 1987, 2, 147-165. [CrossRef] [PubMed]

17. Ott, P.; Clemmesen, O.; Larsen, F.S. Cerebral metabolic disturbances in the brain during acute liver failure: From hyperammonemia to energy failure and proteolysis. Neurochem. Int. 2005, 47, 13-18. [CrossRef] [PubMed]

18. Butterworth, R.F. Pathogenesis of hepatic encephalopathy and brain edema in acute liver failure. J. Clin. Exp. Hepatol. 2015, 5, S96-S103. [CrossRef] [PubMed]

19. Matoori, S.; Leroux, J.-C. Recent advances in the treatment of hyperammonemia. Adv. Drug Deliv. Rev. 2015, 90, 55-68. [CrossRef] [PubMed]

20. Zhu, Z.Y.; Cui, D.; Gao, H.; Dong, F.Y.; Liu, X.C.; Liu, F.; Chen, L.; Zhang, Y.M. Efficient synthesis and activity of beneficial intestinal flora of two lactulose-derived oligosaccharides. Eur. J. Med. Chem. 2016, 114, 8-13. [CrossRef] [PubMed]

21. Al Sibae, M.R.; McGuire, B.M. Current trends in the treatment of hepatic encephalopathy. Ther. Clin. Risk Manag. 2009, 5, 617-626. [PubMed]

22. Bajaj, J.S.; Riggio, O. Drug therapy: Rifaximin. Hepatology 2010, 52, 1484-1488. [CrossRef] [PubMed]

23. Kimer, N.; Krag, A.; Gluud, L.L. Safety, efficacy, and patient acceptability of Rifaximin for hepatic encephalopathy. Patient Prefer. Adherence 2014, 8, 331-338. [PubMed]

24. Barshop, B.A.; Breuer, J.; Holm, J.; Leslie, J.; Nyhan, W.L. Excretion of hippuric acid during sodium benzoate therapy in patients with hyperglycinaemia or hyperammonaemia. J. Inherit. Metab. Dis. 1989, 12, 72-79. [CrossRef] [PubMed]

25. Webster, L.T.; Siddiqui, U.A.; Lucas, S.V.; Strong, J.M.; Mieyal, J.J. Identification of separate Acyl-CoA:Glycine and Acyl-CoA:L-glutamine $\mathrm{N}$-acyltransferase activities in mitochondrial fractions from liver of rhesus monkey and man. J. Biol. Chem. 1976, 251, 3352-3358. [PubMed]

26. Walker, V. Ammonia toxicity and its prevention in inherited defects of the urea cycle. Diabetes Obes. Metab. 2009, 11, 823-835. [CrossRef] [PubMed]

27. Kristiansen, R.G.; Rose, C.F.; Ytrebo, L.M. Glycine and hyperammonemia: Potential target for the treatment of hepatic encephalopathy. Metab. Brain Dis. 2016, 31, 1269-1273. [CrossRef] [PubMed]

28. Pena-Quintana, L.; Llarena, M.; Reyes-Suarez, D.; Aldamiz-Echevarria, L. Profile of sodium phenylbutyrate granules for the treatment of urea-cycle disorders: Patient perspectives. Patient Prefer. Adherence 2017, 11, 1489-1496. [CrossRef] [PubMed]

29. Braissant, O.; Gotoh, T.; Loup, M.; Mori, M.; Bachmann, C. L-arginine uptake, the citrulline-no cycle and arginase II in the rat brain: An in situ hybridization study. Brain Res. Mol. Brain Res. 1999, 70, 231-241. [CrossRef]

30. Haberle, J.; Boddaert, N.; Burlina, A.; Chakrapani, A.; Dixon, M.; Huemer, M.; Karall, D.; Martinelli, D.; Crespo, P.S.; Santer, R.; et al. Suggested guidelines for the diagnosis and management of urea cycle disorders. Orphanet J. Rare Dis. 2012, 7, 32. [CrossRef] [PubMed]

31. Daniotti, M.; la Marca, G.; Fiorini, P.; Filippi, L. New developments in the treatment of hyperammonemia: Emerging use of carglumic acid. Int. J. Gen. Med. 2011, 4, 21. [PubMed]

32. Levrat, V.; Forest, I.; Fouilhoux, A.; Acquaviva, C.; Vianey-Saban, C.; Guffon, N. Carglumic acid: An additional therapy in the treatment of organic acidurias with hyperammonemia? Orphanet J. Rar. Dis. 2008, 3, 2. [CrossRef] [PubMed]

33. Thompson, C.A. Carglumic acid approved to treat genetic hyperammonemia. Am. J. Health Syst. Pharm. 2010, 67, 690. [CrossRef] [PubMed]

34. Tsipotis, E.; Shuja, A.; Jaber, B.L. Albumin dialysis for liver failure: A systematic review. Adv. Chronic Kidney Dis. 2015, 22, 382-390. [CrossRef] [PubMed]

35. Khanna, R.; Nolph, K.D. The physiology of peritoneal dialysis. Am. J. Nephrol. 1989, 9, 504-512. [CrossRef] [PubMed]

36. Mehta, K.P. Dialysis therapy in children. J. Indian Med. Assoc. 2001, 99, 368-373. [PubMed]

37. Rose, C.F. Ammonia-lowering strategies for the treatment of hepatic encephalopathy. Clin. Pharmacol. Ther. 2012, 92, 321-331. [CrossRef] [PubMed]

38. Ahmed, A.; Loes, D.J.; Bressler, E.L. Reversible magnetic resonance imaging findings in metronidazole-induced encephalopathy. Neurology 1995, 45, 588-589. [CrossRef] [PubMed]

39. Morgan, M.H.; Read, A.E.; Speller, D.C. Treatment of hepatic encephalopathy with metronidazole. Gut 1982, 23, 1-7. [CrossRef] [PubMed] 
40. Jover-Cobos, M.; Khetan, V.; Jalan, R. Treatment of hyperammonemia in liver failure. Curr. Opin. Clin. Nutr. Metab. Care 2014, 17, 105-110. [CrossRef] [PubMed]

41. Rockey, D.C.; Vierling, J.M.; Mantry, P.; Ghabril, M.; Brown, R.S., Jr.; Alexeeva, O.; Zupanets, I.A.; Grinevich, V.; Baranovsky, A.; Dudar, L.; et al. Randomized, double-blind, controlled study of glycerol phenylbutyrate in hepatic encephalopathy. Hepatology 2014, 59, 1073-1083. [CrossRef] [PubMed]

42. Jover-Cobos, M.; Noiret, L.; Lee, K.; Sharma, V.; Habtesion, A.; Romero-Gomez, M.; Davies, N.; Jalan, R. Ornithine phenylacetate targets alterations in the expression and activity of glutamine synthase and glutaminase to reduce ammonia levels in bile duct ligated rats. J. Hepatol. 2014, 60, 545-553. [CrossRef] [PubMed]

43. Jover-Cobos, M.; Noiret, L.; Sharifi, Y.; Jalan, R. Ornithine phenylacetate revisited. Metab. Brain Dis. 2013, 28, 327-331. [CrossRef] [PubMed]

44. Rose, C.; Michalak, A.; Pannunzio, P.; Therrien, G.; Quack, G.; Kircheis, G.; Butterworth, R.F. L-ornithine-L-aspartate in experimental portal-systemic encephalopathy: Therapeutic efficacy and mechanism of action. Metab. Brain Dis. 1998, 13, 147-157. [CrossRef] [PubMed]

45. Kircheis, G.; Wettstein, M.; Dahl, S.; Haussinger, D. Clinical efficacy of L-ornithine-L-aspartate in the management of hepatic encephalopathy. Metab. Brain Dis. 2002, 17, 453-462. [CrossRef] [PubMed]

46. Soarez, P.C.; Oliveira, A.C.; Padovan, J.; Parise, E.R.; Ferraz, M.B. A critical analysis of studies assessing L-ornithine-L-aspartate (LOLA) in hepatic encephalopathy treatment. Arq. Gastroenterol. 2009, 46, $241-247$. [CrossRef] [PubMed]

47. Costell, M.; O'Connor, J.E.; Grisolia, S. Protective effect of L-carnitine in experimental high blood ammonium levels. Rev. Clin. Esp. 1984, 173, 169-171. [PubMed]

48. Maldonado, C.; Guevara, N.; Silveira, A.; Fagiolino, P.; Vazquez, M. L-carnitine supplementation to reverse hyperammonemia in a patient undergoing chronic valproic acid treatment: A case report. J. Int. Med. Res. 2017, 45, 1268-1272. [CrossRef] [PubMed]

49. Scaglia, F.; Carter, S.; O’Brien, W.E.; Lee, B. Effect of alternative pathway therapy on branched chain amino acid metabolism in urea cycle disorder patients. Mol. Genet. Metab. 2004, 81 (Suppl. 1), S79-S85. [CrossRef] [PubMed]

50. Dam, G.; Keiding, S.; Munk, O.L.; Ott, P.; Buhl, M.; Vilstrup, H.; Bak, L.K.; Waagepetersen, H.S.; Schousboe, A.; Moller, N.; et al. Branched-chain amino acids increase arterial blood ammonia in spite of enhanced intrinsic muscle ammonia metabolism in patients with cirrhosis and healthy subjects. Am. J. Physiol. Gastrointest. Liver Physiol. 2011, 301, G269-G277. [CrossRef] [PubMed]

51. Tsiaoussis, J.; Newsome, P.N.; Nelson, L.J.; Hayes, P.C.; Plevris, J.N. Which hepatocyte will it be? Hepatocyte choice for bioartificial liver support systems. Liver Transplant. 2001, 7, 2-10. [CrossRef] [PubMed]

52. Ellis, A.J.; Hughes, R.D.; Wendon, J.A.; Dunne, J.; Langley, P.G.; Kelly, J.H.; Gislason, G.T.; Sussman, N.L.; Williams, R. Pilot-controlled trial of the extracorporeal liver assist device in acute liver failure. Hepatology 1996, 24, 1446-1451. [CrossRef] [PubMed]

53. Najimi, M.; Defresne, F.; Sokal, E.M. Concise review: Updated advances and current challenges in cell therapy for inborn liver metabolic defects. Stem Cells Transl. Med. 2016, 5, 1117-1125. [CrossRef] [PubMed]

54. Fisher, R.A.; Strom, S.C. Human hepatocyte transplantation: Worldwide results. Transplantation 2006, 82, 441-449. [CrossRef] [PubMed]

55. Horslen, S.P.; McCowan, T.C.; Goertzen, T.C.; Warkentin, P.I.; Cai, H.B.; Strom, S.C.; Fox, I.J. Isolated hepatocyte transplantation in an infant with a severe urea cycle disorder. Pediatrics 2003, 111, 1262-1267. [CrossRef] [PubMed]

56. Meyburg, J.; Hoffmann, G.F. Liver, liver cell and stem cell transplantation for the treatment of urea cycle defects. Mol. Genet. Metab. 2010, 100 (Suppl. 1), S77-S83. [CrossRef] [PubMed]

57. Kisseleva, T.; Gigante, E.; Brenner, D.A. Recent advances in liver stem cell therapy. Curr. Opin. Gastroenterol. 2010, 26, 395-402. [CrossRef] [PubMed]

58. Sokal, E.M. Treating inborn errors of liver metabolism with stem cells: Current clinical development. J. Inherit. Metab. Dis. 2014, 37, 535-539. [CrossRef] [PubMed]

59. Cunningham, S.C.; Kok, C.Y.; Dane, A.P.; Carpenter, K.; Kizana, E.; Kuchel, P.W.; Alexander, I.E. Induction and prevention of severe hyperammonemia in the spfash mouse model of ornithine transcarbamylase deficiency using shRNA and rAAV-mediated gene delivery. Mol. Ther. 2011, 19, 854-859. [CrossRef] [PubMed] 
60. Hu, C.; Tai, D.S.; Park, H.; Cantero, G.; Chan, E.; Yudkoff, M.; Cederbaum, S.D.; Lipshutz, G.S. Minimal ureagenesis is necessary for survival in the murine model of hyperargininemia treated by AAV-based gene therapy. Gene Ther. 2015, 22, 111-115. [CrossRef] [PubMed]

61. Patil, D.; Westaby, D.; Mahida, Y.; Palmer, K.; Rees, R.; Clark, M.; Dawson, A.; Silk, D. Comparative modes of action of lactitol and lactulose in the treatment of hepatic encephalopathy. Gut 1987, 28, 255-259. [CrossRef] [PubMed]

62. Suraweera, D.; Sundaram, V.; Saab, S. Evaluation and management of hepatic encephalopathy: Current status and future directions. Gut Liver 2016, 10, 509-519. [CrossRef] [PubMed]

63. Descombe, J.J.; Dubourg, D.; Picard, M.; Palazzini, E. Pharmacokinetic study of Rifaximin after oral administration in healthy volunteers. Int. J. Clin. Pharmacol. Res. 1994, 14, 51-56. [PubMed]

64. Sharma, B.C.; Sharma, P.; Lunia, M.K.; Srivastava, S.; Goyal, R.; Sarin, S.K. A randomized, double-blind, controlled trial comparing Rifaximin plus lactulose with lactulose alone in treatment of overt hepatic encephalopathy. Am. J. Gastroenterol. 2013, 108, 1458-1463. [CrossRef] [PubMed]

65. Kimer, N.; Krag, A.; Moller, S.; Bendtsen, F.; Gluud, L.L. Systematic review with meta-analysis: The effects of Rifaximin in hepatic encephalopathy. Aliment. Pharmacol. Ther. 2014, 40, 123-132. [CrossRef] [PubMed]

66. Kikuchi, G.; Motokawa, Y.; Yoshida, T.; Hiraga, K. Glycine cleavage system: Reaction mechanism, physiological significance, and hyperglycinemia. Proc. Jpn. Acad. Ser. B Phys. Biol. Sci. 2008, 84, $246-263$. [CrossRef] [PubMed]

67. Mokhtarani, M.; Diaz, G.A.; Rhead, W.; Berry, S.A.; Lichter-Konecki, U.; Feigenbaum, A.; Schulze, A.; Longo, N.; Bartley, J.; Berquist, W.; et al. Elevated phenylacetic acid levels do not correlate with adverse events in patients with urea cycle disorders or hepatic encephalopathy and can be predicted based on the plasma PAA to PAGN ratio. Mol. Genet. Metab. 2013, 110, 446-453. [CrossRef] [PubMed]

68. Enns, G.M.; Berry, S.A.; Berry, G.T.; Rhead, W.J.; Brusilow, S.W.; Hamosh, A. Survival after treatment with phenylacetate and benzoate for urea-cycle disorders. N. Engl. J. Med. 2007, 356, 2282-2292. [CrossRef] [PubMed]

69. Vilstrup, H.; Amodio, P.; Bajaj, J.; Cordoba, J.; Ferenci, P.; Mullen, K.D.; Weissenborn, K.; Wong, P. Hepatic encephalopathy in chronic liver disease: 2014 practice guideline by the American association for the study of liver diseases and the European association for the study of the liver. Hepatology 2014, 60, 715-735. [CrossRef] [PubMed]

70. Diez-Fernandez, C.; Haberle, J. Targeting CPS1 in the treatment of Carbamoyl phosphate synthetase 1 (CPS1) deficiency, a urea cycle disorder. Expert Opin. Ther. Targets 2017, 21, 391-399. [CrossRef] [PubMed]

71. Abacan, M.; Boneh, A. Use of carglumic acid in the treatment of hyperammonaemia during metabolic decompensation of patients with propionic acidaemia. Mol. Genet. Metab. 2013, 109, 397-401. [CrossRef] [PubMed]

72. Stewart, P.M.; Walser, M. Failure of the normal ureagenic response to amino acids in organic acid-loaded rats. Proposed mechanism for the hyperammonemia of propionic and methylmalonic acidemia. J. Clin. Investig. 1980, 66, 484-492. [CrossRef] [PubMed]

73. Valayannopoulos, V.; Baruteau, J.; Delgado, M.B.; Cano, A.; Couce, M.L.; Del Toro, M.; Donati, M.A.; Garcia-Cazorla, A.; Gil-Ortega, D.; Gomez-de Quero, P.; et al. Carglumic acid enhances rapid ammonia detoxification in classical organic acidurias with a favourable risk-benefit profile: A retrospective observational study. Orphanet J. Rare Dis. 2016, 11, 32. [CrossRef] [PubMed]

74. Sen, S.; Williams, R.; Jalan, R. Emerging indications for albumin dialysis. Am. J. Gastroenterol. 2005, 100, 468-475. [CrossRef] [PubMed]

75. Kribben, A.; Gerken, G.; Haag, S.; Herget-Rosenthal, S.; Treichel, U.; Betz, C.; Sarrazin, C.; Hoste, E.; van Vlierberghe, H.; Escorsell, A.; et al. Effects of fractionated plasma separation and adsorption on survival in patients with acute-on-chronic liver failure. Gastroenterology 2012, 142, 782.e3-789.e3. [CrossRef] [PubMed]

76. Mitzner, S.R. Extracorporeal liver support-albumin dialysis with the molecular adsorbent recirculating system (MARS). Ann. Hepatol. 2011, 10 (Suppl. 1), S21-S28. [PubMed]

77. Oppert, M.; Rademacher, S.; Petrasch, K.; Jorres, A. Extracorporeal liver support therapy with Prometheus in patients with liver failure in the intensive care unit. Ther. Apher. Dial. 2009, 13, 426-430. [CrossRef] [PubMed]

78. De Vecchi, A.F. Peritoneal dialysis in cirrhotic patients. G Ital. Nefrol. 2009, 26, 215-224. [PubMed] 
79. Picca, S.; Dionisi-Vici, C.; Bartuli, A.; de Palo, T.; Papadia, F.; Montini, G.; Materassi, M.; Donati, M.A.; Verrina, E.; Schiaffino, M.C.; et al. Short-term survival of hyperammonemic neonates treated with dialysis. Pediatr. Nephrol. 2015, 30, 839-847. [CrossRef] [PubMed]

80. Conn, H.O.; Leevy, C.M.; Vlahcevic, Z.R.; Rodgers, J.B.; Maddrey, W.C.; Seeff, L.; Levy, L.L. Comparison of lactulose and neomycin in the treatment of chronic portal-systemic encephalopathy. A double blind controlled trial. Gastroenterology 1977, 72, 573-583. [PubMed]

81. Leise, M.D.; Poterucha, J.J.; Kamath, P.S.; Kim, W.R. Management of hepatic encephalopathy in the hospital. In Mayo Clinic Proceedings; Elsevier: Amsterdam, The Netherlands, 2014; pp. 241-253.

82. Davies, N.A.; Wright, G.; Ytrebo, L.M.; Stadlbauer, V.; Fuskevag, O.M.; Zwingmann, C.; Davies, D.C.; Habtesion, A.; Hodges, S.J.; Jalan, R. L-ornithine and phenylacetate synergistically produce sustained reduction in ammonia and brain water in cirrhotic rats. Hepatology 2009, 50, 155-164. [CrossRef] [PubMed]

83. Hadjihambi, A.; de Chiara, F.; Hosford, P.S.; Habtetion, A.; Karagiannis, A.; Davies, N.; Gourine, A.V.; Jalan, R. Ammonia mediates cortical hemichannel dysfunction in rodent models of chronic liver disease. Hepatology 2017, 65, 1306-1318. [CrossRef] [PubMed]

84. Stravitz, R.T.; Gottfried, M.; Durkalski, V.; Fontana, R.J.; Hanje, A.J.; Koch, D.; Hameed, B.; Ganger, D.; Subramanian, R.M.; Bukofzer, S.; et al. Safety, tolerability and pharmacokinetics of L-ornithine phenylacetate in patients with acute liver injury / failure and hyperammonemia. Hepatology 2017. [CrossRef] [PubMed]

85. Kircheis, G.; Nilius, R.; Held, C.; Berndt, H.; Buchner, M.; Gortelmeyer, R.; Hendricks, R.; Kruger, B.; Kuklinski, B.; Meister, H.; et al. Therapeutic efficacy of L-ornithine-L-aspartate infusions in patients with cirrhosis and hepatic encephalopathy: Results of a placebo-controlled, double-blind study. Hepatology 1997, 25, 1351-1360. [CrossRef] [PubMed]

86. Acharya, S.K.; Bhatia, V.; Sreenivas, V.; Khanal, S.; Panda, S.K. Efficacy of L-ornithine L-aspartate in acute liver failure: A double-blind, randomized, placebo-controlled study. Gastroenterology 2009, 136, 2159-2168. [CrossRef] [PubMed]

87. Vazquez, M.; Fagiolino, P.; Maldonado, C.; Olmos, I.; Ibarra, M.; Alvariza, S.; Guevara, N.; Magallanes, L.; Olano, I. Hyperammonemia associated with valproic acid concentrations. Biomed. Res. Int. 2014, 2014, 217269. [CrossRef] [PubMed]

88. Falkenhagen, D.; Strobl, W.; Vogt, G.; Schrefl, A.; Linsberger, I.; Gerner, F.J.; Schoenhofen, M. Fractionated plasma separation and adsorption system: A novel system for blood purification to remove albumin bound substances. Artif. Organs 1999, 23, 81-86. [CrossRef] [PubMed]

89. Rodriguez, J.M.; Murphy, K.; Stanton, C.; Ross, R.P.; Kober, O.I.; Juge, N.; Avershina, E.; Rudi, K.; Narbad, A.; Jenmalm, M.C.; et al. The composition of the gut microbiota throughout life, with an emphasis on early life. Microb. Ecol. Health Dis. 2015, 26, 26050. [CrossRef] [PubMed]

90. Sender, R.; Fuchs, S.; Milo, R. Are we really vastly outnumbered? Revisiting the ratio of bacterial to host cells in humans. Cell 2016, 164, 337-340. [CrossRef] [PubMed]

91. Neish, A.S. Microbes in gastrointestinal health and disease. Gastroenterology 2009, 136, 65-80. [CrossRef] [PubMed]

92. Zhang, Y.-J.; Li, S.; Gan, R.-Y.; Zhou, T.; Xu, D.-P.; Li, H.-B. Impacts of gut bacteria on human health and diseases. Int. J. Mol. Sci. 2015, 16, 7493-7519. [CrossRef] [PubMed]

93. Nicaise, C.; Prozzi, D.; Viaene, E.; Moreno, C.; Gustot, T.; Quertinmont, E.; Demetter, P.; Suain, V.; Goffin, P.; Deviere, J. Control of acute, chronic, and constitutive hyperammonemia by wild-type and genetically engineered Lactobacillus plantarum in rodents. Hepatology 2008, 48, 1184-1192. [CrossRef] [PubMed]

94. Luo, J.; Wang, T.; Liang, S.; Hu, X.; Li, W.; Jin, F. Ingestion of Lactobacillus strain reduces anxiety and improves cognitive function in the hyperammonemia rat. Sci. China Life Sci. 2014, 57, 327-335. [CrossRef] [PubMed]

95. Macbeth, W.A.; Kass, E.; Mcdermott, W. Treatment of hepatic encephalopathy by alteration of intestinal flora with Lactobacillus acidophilus. Lancet 1965, 285, 399-403. [CrossRef]

96. Loguercio, C.; Blanco, C.D.V.; Coltorti, M. Enterococcus lactic acid bacteria strain SF68 and lactulose in hepatic encephalopathy: A controlled study. J. Int. Med. Res. 1987, 15, 335-343. [CrossRef] [PubMed]

97. Bajaj, J.S.; Heuman, D.M.; Hylemon, P.B.; Sanyal, A.J.; Puri, P.; Sterling, R.K.; Luketic, V.; Stravitz, R.T.; Siddiqui, M.S.; Fuchs, M. Randomised clinical trial: Lactobacillus GG modulates gut microbiome, metabolome and endotoxemia in patients with cirrhosis. Aliment. Pharmacol. Ther. 2014, 39, 1113-1125. [CrossRef] [PubMed] 
98. Bajaj, G.; Hau, A.M.; Hsu, P.; Gafken, P.R.; Schimerlik, M.I.; Ishmael, J.E. Identification of an atypical calcium-dependent calmodulin binding site on the C-terminal domain of GluN2A. Biochem. Biophys. Res. Commun. 2014, 444, 588-594. [CrossRef] [PubMed]

99. Dhiman, R.K.; Rana, B.; Agrawal, S.; Garg, A.; Chopra, M.; Thumburu, K.K.; Khattri, A.; Malhotra, S.; Duseja, A.; Chawla, Y.K. Probiotic VSL\# 3 reduces liver disease severity and hospitalization in patients with cirrhosis: A randomized, controlled trial. Gastroenterology 2014, 147, 1327.e3-1337.e3. [PubMed]

100. Liu, Q.; Duan, Z.P.; Ha, D.K.; Bengmark, S.; Kurtovic, J.; Riordan, S.M. Synbiotic modulation of gut flora: Effect on minimal hepatic encephalopathy in patients with cirrhosis. Hepatology 2004, 39, 1441-1449. [CrossRef] [PubMed]

101. Bongaerts, G.; Severijnen, R.; Timmerman, H. Effect of antibiotics, prebiotics and probiotics in treatment for hepatic encephalopathy. Med. Hypotheses 2005, 64, 64-68. [CrossRef] [PubMed]

102. Bajaj, D.; Chahal, P. A case of multiple misdiagnoses in a septuagenarian. Am. J. Med. 2014, 127, e15-e16. [CrossRef] [PubMed]

103. McGee, R.G.; Bakens, A.; Wiley, K.; Riordan, S.M.; Webster, A.C. Probiotics for patients with hepatic encephalopathy. Cochrane Libr. 2011. [CrossRef]

104. Goffin, P.; Deghorain, M.; Mainardi, J.-L.; Tytgat, I.; Champomier-Verges, M.-C.; Kleerebezem, M.; Hols, P. Lactate racemization as a rescue pathway for supplying D-lactate to the cell wall biosynthesis machinery in Lactobacillus plantarum. J. Bacteriol. 2005, 187, 6750-6761. [CrossRef] [PubMed]

105. Soupene, E.; He, L.; Yan, D.; Kustu, S. Ammonia acquisition in enteric bacteria: Physiological role of the ammonium/methylammonium transport B (AMTB) protein. Proc. Natl. Acad. Sci. USA 1998, 95, 7030-7034. [CrossRef] [PubMed]

106. Kankainen, M.; Paulin, L.; Tynkkynen, S.; von Ossowski, I.; Reunanen, J.; Partanen, P.; Satokari, R.; Vesterlund, S.; Hendrickx, A.P.; Lebeer, S. Comparative genomic analysis of Lactobacillus rhamnosus GG reveals pili containing a human-mucus binding protein. Proc. Natl. Acad. Sci. USA 2009, 106, 17193-17198. [CrossRef] [PubMed]

107. Jia, L.; Zhang, M.-H. Comparison of probiotics and lactulose in the treatment of minimal hepatic encephalopathy in rats. World J. Gastroenterol. 2005, 11, 908. [CrossRef] [PubMed]

108. Sartor, R.B. Therapeutic manipulation of the enteric microflora in inflammatory bowel diseases: Antibiotics, probiotics, and prebiotics. Gastroenterology 2004, 126, 1620-1633. [CrossRef] [PubMed]

109. Hedin, C.; Whelan, K.; Lindsay, J.O. Evidence for the use of probiotics and prebiotics in inflammatory bowel disease: A review of clinical trials. Proc. Nutr. Soc. 2007, 66, 307-315. [CrossRef] [PubMed]

110. Shimizu, K.; Ogura, H.; Asahara, T.; Nomoto, K.; Morotomi, M.; Tasaki, O.; Matsushima, A.; Kuwagata, Y.; Shimazu, T.; Sugimoto, H. Probiotic/synbiotic therapy for treating critically ill patients from a gut microbiota perspective. Digest. Dis. Sci. 2013, 58, 23-32. [CrossRef] [PubMed]

111. Sheth, A.A.; Garcia-Tsao, G. Probiotics and liver disease. J. Clin. Gastroenterol. 2008, 42, S80-S84. [CrossRef] [PubMed]

112. Bass, N.M.; Mullen, K.D.; Sanyal, A.; Poordad, F.; Neff, G.; Leevy, C.B.; Sigal, S.; Sheikh, M.Y.; Beavers, K.; Frederick, T. Rifaximin treatment in hepatic encephalopathy. N. Engl. J. Med. 2010, 362, 1071-1081. [CrossRef] [PubMed]

113. Shen, T.-C.D.; Albenberg, L.; Bittinger, K.; Chehoud, C.; Chen, Y.-Y.; Judge, C.A.; Chau, L.; Ni, J.; Sheng, M.; Lin, A. Engineering the gut microbiota to treat hyperammonemia. J. Clin. Investig. 2015, 125, 2841. [CrossRef] [PubMed]

114. Clay, D.; Malzer, G.; Anderson, J. Ammonia volatilization from urea as influenced by soil temperature, soil water content, and nitrification and hydrolysis inhibitors. Soil Sci. Soc. Am. J. 1990, 54, 263-266. [CrossRef]

115. Konieczna, I.; Zarnowiec, P.; Kwinkowski, M.; Kolesinska, B.; Fraczyk, J.; Kaminski, Z.; Kaca, W. Bacterial urease and its role in long-lasting human diseases. Curr. Protein Pept. Sci. 2012, 13, 789-806. [CrossRef] [PubMed]

116. Romero-Gómez, M.; Jover, M.; Galán, J.J.; Ruiz, A. Gut ammonia production and its modulation. Metab. Brain Dis. 2009, 24, 147-157. [CrossRef] [PubMed]

117. Aldridge, D.R.; Tranah, E.J.; Shawcross, D.L. Pathogenesis of hepatic encephalopathy: Role of ammonia and systemic inflammation. J. Clin. Exp. Hepatol. 2015, 5, S7-S20. [CrossRef] [PubMed] 
118. Bajaj, J.S.; Betrapally, N.S.; Hylemon, P.B.; Thacker, L.R.; Daita, K.; Kang, D.J.; White, M.B.; Unser, A.B.; Fagan, A.; Gavis, E.A. Gut microbiota alterations can predict hospitalizations in cirrhosis independent of diabetes mellitus. Sci. Rep. 2015, 5, 18559. [CrossRef] [PubMed]

119. Shah, N.L.; Banaei, Y.P.; Hojnowski, K.L.; Cornella, S.L. Management options in decompensated cirrhosis. Hepatic Med. Evid. Res. 2015, 7, 43. [CrossRef] [PubMed]

120. Zhang, Z.; Zhai, H.; Geng, J.; Yu, R.; Ren, H.; Fan, H.; Shi, P. Large-scale survey of gut microbiota associated with MHE via 16S rRNA-based pyrosequencing. Am. J. Gastroenterol. 2013, 108, 1601-1611. [CrossRef] [PubMed]

121. Chen, Y.; Yang, F.; Lu, H.; Wang, B.; Chen, Y.; Lei, D.; Wang, Y.; Zhu, B.; Li, L. Characterization of fecal microbial communities in patients with liver cirrhosis. Hepatology 2011, 54, 562-572. [CrossRef] [PubMed]

122. Qin, N.; Yang, F.; Li, A.; Prifti, E.; Chen, Y.; Shao, L.; Guo, J.; Le Chatelier, E.; Yao, J.; Wu, L.; et al. Alterations of the human gut microbiome in liver cirrhosis. Nature 2014, 513, 59-64. [CrossRef] [PubMed]

123. Kumar, J.; Bajaj, P.; Singh, H.; Mishra, G.P.; Srivastava, R.B.; Naik, P.K. Utilization of intron-flanking EST-specific markers in the genetic characterization of Artemisia annua genotypes from the trans-Himalayan region of Ladakh, India. J. Environ. Biol. 2012, 33, 991-997. [PubMed]

124. Mao, S.; Zhang, M.; Liu, J.; Zhu, W. Characterising the bacterial microbiota across the gastrointestinal tracts of dairy cattle: Membership and potential function. Sci. Rep. 2015, 5. [CrossRef] [PubMed]

125. Dewhirst, F.E.; Chien, C.-C.; Paster, B.J.; Ericson, R.L.; Orcutt, R.P.; Schauer, D.B.; Fox, J.G. Phylogeny of the defined murine microbiota: Altered Schaedler flora. Appl. Environ. Microbiol. 1999, 65, 3287-3292. [PubMed]

126. Butterworth, R.F.; Giguère, J.-F.; Michaud, J.; Lavoie, J.; Layrargues, G.P. Ammonia: Key factor in the pathogenesis of hepatic encephalopathy. Mol. Chem. Neuropathol. 1987, 6, 1-12. [CrossRef]

(C) 2018 by the authors. Licensee MDPI, Basel, Switzerland. This article is an open access article distributed under the terms and conditions of the Creative Commons Attribution (CC BY) license (http:/ / creativecommons.org/licenses/by/4.0/). 